\title{
The impact of land use on future water balance - A simple approach for analysing climate change effects
}

\author{
András Herceg, \\ Péter Kalicz, \\ Zoltán Gribovszki
}

Regional climate change projections for Europe agree in predicting a statistically significant warming in all seasons. The most significant climate change effect is its impact on water cycle through altering precipitation patterns and evapotranspiration processes at multiple scales. The anticipated changes in the distribution and precipitation amounts together with continuously increasing temperatures may induce a higher rate of water consumption in plants, which can generate changes in soil moisture, groundwater, and the water cycle. Thus, climate change can cause changes in the water balance equations structure. A Thornthwaite-type monthly step water balance model was established to compare the water balance in three different surface land cover types: (i) a natural forested area; (ii) a parcel with mixed surface cover; (iii) an agricultural area. The key parameter of the model is the water storage capacity of the soil. Maximal rooting depth of the given area is also determinable during the calibration process using actual evapotranspiration (AET) and soil physical data. The locally calibrated model was employed for assessing future AET and soil moisture of selected land cover types using data from four biascorrected regional climate models. The projections demonstrate increasing actual evapotranspiration values in each surface cover type at the end of the $21^{\text {st }}$ century. Regarding the $10^{\text {th }}$ percentile minimum soil moisture values, the forested area displayed an increasing trend, while the agricultural field and mixed parcel showed a strong decrease. The 30-year monthly means of evapotranspiration shows the maximum values in June and July, while the minimum soil moisture in September. Water stress analysis indicates water stress is expected to occur only in the agricultural field during the $21^{\text {st }}$ century. The comparison of the three surface covers reveals that forest has the greatest soil water storage capacity due to the highest rooting depth. Thus, according to the projections for $21^{\text {st }}$ century, less water stress is predicted to occur at the forested area compared to the other two surface covers which shows shallow rooting depth.

Keywords: Water Balance, Climate Change, Plant Available Water, Evapotranspiration, Soil Moisture, Water Stress

Basin, the climate projections for the $21^{\text {st }}$ century indicate an increase of temperature (expected in all seasons) and an increase of climatic aridity. The projected change could be between $2-5{ }^{\circ} \mathrm{C}$, depending on the applied climate model and emission scenario (Pongrácz et al. 2011, Nováky \& Bálint 2013).

Higher temperatures reflect larger energy potentials in the atmosphere, which, therefore, contains more water at the same time and/or has a shorter water vapour retention time, both of which will accelerate the hydrological cycle (Cui et al. 2018, IPCC 2019). This acceleration means temporal distribution changes of the precipitation, which often results in increased precipitation amounts during single events, though not affecting the annual rainfall amount which remains constant. Therefore, warming has also an effect on the hydrological cycle through precipitation intensity (Kjellström et al. 2011). The Carpathian Basin may experience a decrease of the precipitation amount in summer and an increase in winter (Nováky \& Bálint 2013, Gálos et al. 2015).

The most significant effect of climate change is its impact on the water cycle by altering precipitation patterns and evapotranspiration processes at multiple scales (Sun et al. 2011). The forecasted changes in the distribution and amount of precipitation along with the continuously increasing temperature may lead to a higher water consumption in plants (due to the longer growing seasons, and larger leaf area Aber et al. 2009), which will generate changes in soil moisture, groundwater (Mas-Pla \& Menció 2019), and the water cycle. Thus, climate change can cause changes in the water balance equations structure (Keve \& Nováky 2010).

In the Carpathian Basin, 90\% of the precipitation is evapotranspired, while the remaining $10 \%$ is runoff (Kovács 2011). This large influence of vegetation on the water cycle makes modelling necessary to attain a quantitative understanding of the evapotranspiration process. 
Previous studies modeling the impact of climate change on water balance (Lutz et al. 2010, Remrová \& Císlerová 2010, Van Der Linden et al. 2019, Csáki et al. 2020) revealed that evapotranspiration may increase, but soil water content may decrease in the future due to presumably increasing temperatures and decreasing precipitation, thereby leading to possible enhanced water scarcity towards the end of the $21^{\text {st }}$ century. Thus, modelling the expected changes in water resources over different time scales can be crucial for water management, agriculture, forestry, and civil engineering in the Carpathian Basin region (Gáspár et al. 2017, Hlásny et al. 2014, Mátyás et al. 2018). Consequently, further studies at the regional scale are required (Stagl et al. 2014).

The overall objectives of this study are to establish a monthly step water balance model for three different surface covers: (i) a forested area; (ii) a mixed parcel $\left(1 \mathrm{~km}^{2}\right.$ corn field plot with strips of poplar trees); (iii) an agricultural area. Using the calibrated model, the impact of climate change in the $21^{\text {st }}$ century is analysed to compare the water balance of forest and two other land use types located at the north-western part of the Carpathian Basin.

\section{Materials and methods}

\section{Study area}

To test our model, we used three study areas in the Carpathian Basin, namely: a forested area, a mixed parcel, and an agricultural field. The first two are situated in the Western part of the Transdanubian Region of Hungary, while the third is in the eastern part of Austria next to Vienna (see Fig. S1 in Supplementary material).

\section{Forested area}

The forested area is an experimental catchment at the eastern foothills of the Alps near the city of Sopron. The elevation of the study area ranges from 370 to $550 \mathrm{~m}$ a.s.l.

This area has a subalpine climate, with an average annual temperature of $8.5^{\circ} \mathrm{C}$, and annual precipitation of $700-750 \mathrm{~mm}$. The driest season is autumn, while the wettest is late spring and early summer (Dövényi 2010).

The geological basis of the catchment is fluvial sediments deposited in five distinct layers in the tertiary (Miocene) period on crystalline bedrock. A finer-grained layer appears in the valley bottom, which is a good aquifer, giving rise to perennial streams (Kisházi \& Ivancsics 1985). The soil texture of this area is loam. The dominant vegetation in the catchment comprises alder (Alnus glutinosa) in the bottom of the valley, spruce (Picea abies), and beech ( $\mathrm{Fa}$ gus sylvatica) on the northern slopes, whereas sessile oak (Quercus petraea) and beech (Fagus sylvatica) are on the southern slopes.
The investigation period was from January 2000 to December 2008, due to the availability of the data which originated from the AgroClimate. 2 project (Czimber 2018).

Mean monthly temperature $\left(T_{M}\right)$ and monthly summed precipitation $\left(P_{M}\right)$ values are utilized as inputs for the forested area and measured (remote-sensing based) actual evapotranspiration values (ET for calibration and validation.

Szilágyi et al. (2011) established a method called CREMAP to downscale the regional actual evapotranspiration values into spatially variable actual evapotranspiration rates. The CREMAP model is a modified, upgraded version of the ET estimation technique of Szilágyi \& Józsa (2009). The model provides a measure of actual evapotranspiration through a satellite-based, remote-sensed approach. Kovács (2011) mapped the monthly actual evapotranspiration (ET $T_{\text {CREMAP }}$ ) for Hungary from 2000 to 2008 using the Szilágyi CREMAP method. The base of the method is a linear transformation of the eight-day composited MODIS (Moderate Resolution Imaging Spectroradiometer) daytime surface temperature values into actual evapotranspiration rates (Szilágyi \& Józsa 2009). These monthly actual evapotranspiration maps were prepared from March until November of each year.

\section{Mixed parcel}

The mixed parcel is basically used as an agricultural plot and was formerly a cornfield, except during the period 2003-2007 when it was used to grow barley and in 2004 when it was used for wheat. However, poplar (Populus $\times$ canadensis) trees can also be found along strips in this area. The parcel has a total area of about $1 \mathrm{~km}^{2}$, and the elevation is $120 \mathrm{~m}$ a.s.l.

The selected parcel is located in the Mosoni-sík microregion that is situated in Győr-Moson-Sopron County. It is basically (73.5\%) plough-land. On the whole, this natural microregion is an alluvial plain (Dövényi 2010).

The climate is continental, with temperature differences between the western and eastern part of the natural microregion. The average annual temperature is $9.7{ }^{\circ} \mathrm{C}$ and the annual precipitation is $560 \mathrm{~mm}$ (Dövényi 2010).

The investigation period was from January 2000 to December 2008, the same as for the forested area. The data originated from the AgroClimate.2 project (Czimber 2018).

The input dataset contains mean monthly temperature $\left(T_{M}\right)$ and monthly summed precipitation $\left(P_{M}\right)$ values as well as measured (remote-sensing) actual evapotranspiration values (ET CREMAP) for calibration and validation.

\section{Agricultural field}

The agricultural field is an area of about $1000 \mathrm{~km}^{2}$ in the eastern part of Austria, be- tween Vienna and the border of Slovakia. The elevation of this study area is $157 \mathrm{~m}$ a.s.l. It is characterized by a subhumid climate with a mean annual temperature and precipitation of approximately $10{ }^{\circ} \mathrm{C}$ and $550 \mathrm{~mm}$, respectively. Typical summers are hot and dry, while winters are mainly cold with severe frost and limited snow cover (Götz et al. 2000). A typical soil type is chernozem, a black-coloured fertile soil (Götz et al. 2000). The favourable environmental conditions supported the development of large areas $\left(650 \mathrm{~km}^{2}\right)$ of intensive production of various crops in the past decades. As the region is prone to water deficit stress, irrigation is common and is expected to become even more important due to climate change effects (Nachtnebel et al. 2014).

Basic data for this study were obtained at the experimental farm of the University of Natural Resources and Life Sciences, Vienna (BOKU), in Groß-Enzersdorf $\left(48^{\circ} 12^{\prime} \mathrm{N}\right.$, $16^{\circ} 34^{\prime} \mathrm{E} ; 157 \mathrm{~m}$ a.s.l.). Regarding climate conditions, the location is representative for the agricultural field (Nolz et al. 2016).

Mass changes of the surface-soil-vegetation system and, therefore, changes in soil water content can be estimated using weighing lysimeters (Baumgartner \& Liebscher 1995, Nolz et al. 2014). Soil water balance components were determined using a large weighing lysimeter. During installation, a typical soil profile was created by repacking soil in layers as follows: (i) sandy loam soil $(0-140 \mathrm{~cm}$, porosity $35-40 \%-30 \%$ sand, $50 \%$ silt, $20 \%$ clay; porosity: $43 \%$ ); (ii) gravel $(140-250 \mathrm{~cm}$, only macropores with negligible water holding capacity).

These soil characteristics and the consequent hydraulic properties were taken as the basis for the simulation. Although the input parameters are assumed to be typical for the region, a single soil profile cannot represent the characteristics of a large area like the agricultural field in general.

The utilized lysimeter and the surrounding area were permanently covered by grass and maintained to represent the standard conditions for the determination of reference evapotranspiration (Allen et al. 1998).

Eqn. 1 illustrates the relation between measured $\left(\mathrm{W}_{\text {lys }}, \mathrm{W}_{\text {drain }}\right)$ and unknown $\left(\mathrm{P}_{\mathrm{lys}}\right.$, $\mathrm{I}_{\text {lys }}, \mathrm{ET}_{\text {lys }}$ ) water balance components based on daily changes ( $\Delta-$ eqn. 1$)$ :

$\Delta W_{l y s}+\Delta W_{\text {drain }}=\Delta P_{l y s}+\Delta I_{l y s}-\Delta E T_{l y s}$

Therein, $\Delta \mathrm{W}_{\mathrm{lys}}$ is the daily change of the soil water mass, determined by means of the weighing facility. $\Delta \mathrm{W}_{\text {drain }}$ is the daily amount of drainage water (freely draining by gravity forces), measured at the bottom outlet by means of a tipping bucket device. $\mathrm{P}_{\text {lys }}$ is precipitation and $\mathrm{I}_{\mathrm{lys}}$ is irrigation on the lysimeter. Both were assumed to occur when net changes in soil water $\left(\Delta \mathrm{W}_{\text {lys }}+\right.$ $\Delta \mathrm{W}_{\text {drain }}$ ) were positive. Consequently, evapotranspiration from the lysimeter surface (ET lys) was quantified as negative changes 
in soil water $\left(\Delta \mathrm{W}_{\text {lys }}+\Delta \mathrm{W}_{\text {drain }}\right)$. All units are millimetres per day $\left(\mathrm{mm} \mathrm{day}^{-1}\right)$. Specific smoothing functions were applied to improve measurement accuracy, which is 0.1 $\mathrm{mm}$ at average wind velocity. A detailed description of measurements and data processing can be found in Nolz et al. (2014, 2016)

Mean monthly temperature $\left(\mathrm{T}_{M}\right)$ and summed monthly precipitation $\left(P_{M}\right)$ values make the input dataset, and the actual evapotranspiration values (ET LYSIMETER $_{\text {) }}$ are for calibration and validation. Nevertheless, all input data refer to the experimental site in Groß-Enzersdorf. In the given case, irrigation and precipitation comprise the input parameter.

The investigation period was from January 2004 to December 2011. It is important to note that the difference between the time series of the study areas is due to the availability of the input data.

\section{The Thornthwaite-type hydrological} model description

The Thornthwaite-type water balance model represents a 1-D system which considers only vertical fluxes. Input values are monthly precipitation $\left(\mathrm{P}_{\mathrm{M}}, \mathrm{mm}\right)$ and temperature $\left(T_{M},{ }^{\circ} \mathrm{C}\right.$ - Dingman 2002). To develop the Thornthwaite-type water balance model, we have chosen the $\mathrm{R}$ statistical software ( $R$ Core Team 2012).

The first step in setting up the model was the calculation of the potential evapotranspiration (PET). PET is the amount of water that can be evaporated and transpired when soil water is sufficient to meet atmospheric demand (Allen et al. 1998). In this study, a temperature-based PET-model after Hamon (1963) was applied. The calculation of potential evapotranspiration after Hamon $\left(\mathrm{PET}_{\mathrm{H}}\right)$ is described by the following equations (eqn. 2, eqn. 3):

$$
\begin{aligned}
& P E T_{H}=29.8 \cdot D \frac{e_{m}^{*}}{T_{M}+273.2} \\
& e_{m}^{*}=0.611 \cdot \exp \left(\frac{17.3 \cdot T_{M}}{T_{M}+237.3}\right)
\end{aligned}
$$

where $D$ is the day length (hr), $T_{M}$ is the average monthly temperature $\left({ }^{\circ} \mathrm{C}\right)$, and $\mathrm{e}_{\mathrm{m}}{ }_{\mathrm{m}}$ is the saturation vapour pressure $(\mathrm{kPa})$.

The next step was a condition. If $\mathrm{P}_{M} \geq$ $\mathrm{PET}_{M}$ then $\mathrm{ET}_{M}=\mathrm{PET}_{M}$ and (eqn. 4):

$$
\begin{gathered}
S O I L_{M}=\min \left\{\left[\left(P_{M}-E T_{M}\right)+S O I L_{M-1}\right],\right. \\
\left.S O I L_{M A X}\right\}
\end{gathered}
$$

where $\mathrm{PET}_{\mathrm{M}}$ is the calibrated monthly potential evapotranspiration $(\mathrm{mm})$. Determination of $\mathrm{PET}_{\mathrm{M}}$ is part of the calibration, which will be described later. $\mathrm{ET}_{M}$ ( $\mathrm{mm}$ month-1) is the monthly actual evapotranspiration, and $\mathrm{SOIL}_{M}(\mathrm{~mm})$ is the monthly soil moisture. Actual evapotranspiration is the amount of water evaporating from the surface and transpired by plants if the total amount of water is limited (Mingteh 2006). $\mathrm{SOIL}_{M}$ represents the amount of soil water available for the vegetation (which is differ- ent from the total amount of soil water). Both $\mathrm{ET}_{M}$ and $\mathrm{SOIL}_{M}$ denote the key components of this study.

For the simulation procedure, the first $\mathrm{SOIL}_{\mathrm{M}-1}$ value was set to a maximum value that corresponds with the soil-water storage capacity ( $\mathrm{SOIL}_{\text {MAX }}, \mathrm{mm}$ ). The basic assumption was that soil is saturated before the beginning of the vegetative period. SOIL MAx $_{\text {Was introduced using unsaturated }}$ hydraulic parameters of the study areas' soil types and setting a rooting depth of 1 $\mathrm{m}$ (eqn. 5):

$$
S O I L_{M A X}=\left(\theta_{f c}-\theta_{p w p}\right) \cdot z_{r z}
$$

where $\theta_{\mathrm{fc}}$ is the water content at field capacity (dimensionless), $\theta_{\text {pwp }}$ is the water content at permanent wilting point (dimensionless), $\mathrm{z}_{\mathrm{rz}}$ is the rooting depth (vertical extent of root zone, in $\mathrm{mm}$ ).

The following procedure illustrates how soil water storage is considered as a reservoir for evapotranspiration: if precipitation is less than the (calibrated) potential evapotranspiration in a certain month (i.e., $\mathrm{P}_{\mathrm{M}}<$ $\mathrm{PET}_{M}$ ), then (eqn. 6):

$$
\begin{aligned}
E T_{M} & =P_{M}+S O I L_{M-1}-S_{S O I L} \\
& =P_{M}+\Delta S O I L
\end{aligned}
$$

where (eqn. 7):

$$
\begin{aligned}
& \Delta S O I L=S O I L_{M-1}-S O I L_{M} \\
& =S O I L_{M-1} \cdot\left[1-\exp \left(-\frac{P E T_{M}-P_{M}}{S O I L_{M A X}}\right)\right]
\end{aligned}
$$

and $\triangle$ SOIL is the decrease in soil water storage [mm].

\section{Model calibration and validation}

Remote sensing based (for the forested area and mixed parcel) and grass-covered lysimeters (for the agricultural field) actual evapotranspiration data served as basis for calibration and validation. The available time series for the forested area and for the mixed parcel (2000-2008) was divided into two parts. The first part is used for calibration from 2000 to 2005, whereas the second is for validation from 2006 to 2008 . In the agricultural field, the time series (2004-2011) was also divided into two parts. The first (from 2004 to 2008) was used for calibration and the second (from 2009 to 2011) for validation.

The calibration datasets were further divided into two parts considering both potential and actual evapotranspiration. The results of calibration and validation are reported in the Results section.

Fig. S2 (Supplementary material) schematically represents the functioning of the model and the relationships between the applied parameters in the modelling process for the forested area and mixed parcel.

Parameters of the calibration and the input data $\left(T_{M}\right.$ and $\left.P_{M}\right)$ of the validation period (2009-2011 for the agricultural field; 2006-2008 for the forested area and the mixed parcel) were used for the validation.

\section{Projection procedure}

As the basis for the projection procedure, the water balance model was re-calibrated for each study area using all available data (2000-2008 for the forested area and mixed parcel; and 2004-2011 for the agricultural field). This was done because model calibration using as much data as possible was assumed to deliver the best possible results.

Inputs for predicting future developments of actual evapotranspiration ( $\mathrm{ET}_{\mathrm{M}}$ ), soil moisture $\left(\mathrm{SOIL}_{M}\right)$, and the lower $10^{\text {th }}$ percentile of soil moisture (SOIL $\mathrm{M}_{1}$ 10Perc, i.e., mean of the values below the $10^{\text {th }}$ percentile of the soil moisture) were the equations of the broken line regression (details in the Results section), the calibrated SOIL $_{\text {MAX }}$ values, and projected temperature $\left(T_{M}\right)$ and precipitation $\left(P_{M}\right)$ values. The latter two originate from four grid-based, bias-corrected regional climate models (RCMs - FORESEE database).

\section{FORESEE database}

FORESEE is a bias-adjusted database that contains daily meteorological data ( $\mathrm{min} /$ max temperature and precipitation) based on the simulation results of ten RCMs for 2015-2100, and observation based data for the period 1951-2014 interpolated to $1 / 6 \times 1 / 6$ degree spatial (horizontal) resolution grid (using inverse distance interpolation technique). Furthermore, all of the time series were converted to a 365-day calendar (Dobor et al. 2013). It should be noted that each of the used RCM data are based on the $A 1 B$ greenhouse gas emission scenario (i.e., a balanced emphasis on all energy sources).

\section{Regional climate models}

The four different RCMs illustrate the uncertainties, because all climate projections have inherent uncertainties. Data were extracted from the pixel including the study sites' coordinates. The main properties of the RCMs can be found in Tab. S1 (Supplementary material). In the following, each model will be referred to by their model ID (first column of Tab. S1).

The time scale of RCMs covers a range from 2015 to 2100. Each contains temperature and precipitation data in monthly time intervals. To evaluate the results for the $21^{\text {st }}$ century, four main investigation periods were designated: 1985-2015 (01.01.1985 01.01.2015), 2015-2045 (01.01.2015 01.01.2045), 2045-2075 (01.01.2045 $01.01 .2075)$, and 2070-2100 (01.01.2070 $01.01 .2100)$. The results of the first investigation period (1985-2015) are based on observation data (model ID "o"). As mentioned before, the FORESEE results for the RCMs were available from 2015; therefore, the investigation periods had to be shifted by five years compared to the investigation periods of the AgroClimate.2 project. With the data at hand, these 30-year-blocks with a five-year overlap in the last two periods seemed the best partitioning. The overlap 
in the last part of the $21^{\text {st }}$ century was nec essary because only 25 years of data were available.

\section{Water stress}

An appropriate and simple way to assess water stress is the calculation of the relative extractable water (REW, dimensionless) using the following equation (Granier et al. 1999) - eqn. 8):

$$
R E W=\frac{S O I L_{M}}{S O I L_{M A X}}
$$

When REW drops below $50 \%$ of SOIL $_{\text {MAX, }}$ the transpiration is progressively reduced (because of stomatal closure); hence, plant water stress is assumed to occur. SOIL $\mathrm{LAX}_{\mathrm{X}}$ parameter is the maximal amount of water available to plants and, therefore, it reflects the maximum extractable water in the soil. The average soil moisture $\left(\mathrm{SOIL}_{M}\right)$ is the extractable water in the different periods of investigation.

\section{Evaluating model performance}

Model performance was tested using the coefficient of determination $\left(R^{2}\right)$ and the Nash-Sutcliffe model efficiency coefficient $\left(R^{2} \mathrm{NS}\right)$. The latter is a criterion used for calibration and validation of hydrologic models (eqn. 9):

$$
R_{N S}^{2}=1-\frac{\sum_{i=1}^{N}\left(E T_{M S R_{i}}-E T_{S I M_{i}}\right)^{2}}{\sum_{i=1}^{N}\left(E T_{{M S R_{i}}_{i}}-m_{M S R_{i}}\right)^{2}}
$$

where $\mathrm{ET}_{\mathrm{MSR} i}$ is the time series of measured values, $\mathrm{ET}_{\mathrm{SIM} i}$ is the time series of simulated values, and $\mathrm{m}_{\text {MSR }}$ is the average value for the considered period.

\section{Results}

\section{Methodical results}

\section{Calibration of the potential} evapotranspiration

The first step of calibration considered the potential evapotranspiration for actual land cover using ET $_{\text {CREMAP}}$-values (for the forested area and mixed parcel) and $\mathrm{Et}_{\mathrm{lys}}$ values (for the agricultural field) at wellwatered conditions. The latter were assumed to occur when precipitation or the actual evapotranspiration (ET $\mathrm{T}_{\text {CREMAP }}$ or $\mathrm{ET}_{\mathrm{lyS}}$ ) exceeded the potential evapotranspiration ( $\mathrm{PET}_{\mathrm{H}}$ - eqn. 10):

$$
P_{M}>P E T_{H} \text { or } E T_{\text {lys }} / E T_{\text {CREMAP }}>P E T_{H}
$$

The $E T_{\text {lys }} / E T_{\text {CREMAP }}$ values selected in such a way are denoted $P E T_{\text {IYS }} / \mathrm{PET}_{\text {CREMAP. }}$. Measured ( $\mathrm{PET}_{\text {lys }} / \mathrm{PET}_{\text {CREMAP }}$ ) and calculated ( $\mathrm{PET}_{\mathrm{H}}$ ) values were correlated with the second variable as the explanatory one. PET is known to be different between growing season and dormancy, therefore different relationships had to be established for the two periods (Rao et al. 2011). For this purpose, a software package named "segmented" of $R$ software environment was applied ( $R$ Core Team 2012). The bases are the socalled broken-line or segmented models that create a piecewise linear relationship between the response and one or more of the explanatory variables. This linear relationship is represented by two or more straight lines connected at unknown values called breakpoints (Muggeo 2008).

We compared the three study areas regarding PET calibration. Correlation between $\mathrm{PET}_{\mathrm{H}}$ and $\mathrm{PET}_{\text {CREMAP}} / \mathrm{LYS}$ during the period of dormancy is illustrated by the section on the left of the vertical dotted line (broken-line approach) in Fig. 1. This comparison revealed that each area has a high correlation between PET CREMAP/LYs and $\mathrm{PET}_{\mathrm{H}}$, as reflected by the high coefficient of determination ( $\mathrm{R}^{2}=0.98$ in each case).

The 1:1 dotted lines exposed overestimation in the forested area (Fig. 1a) and mixed parcel (Fig. 1b), though only during the dormancy period. Therefore, the globally calibrated, calculated Hamon type PET has higher values than the measured PET in the winter seasons, as indicated by the lines of the first segment appearing under the 1:1 lines (Fig. 1a, Fig. 1b). Conversely, the agricultural field provides proper estimations for the dormant season, which means greater $\mathrm{PET}_{\mathrm{H}}$ values as well. However, only two values of lysimeter data (red triangles) could be related to this period, thus little could be concluded (Fig. 1C).

The breakpoint value obtained for the forested area $(24.3 \mathrm{~mm})$ is lower than the two other areas (mixed parcel: $39.1 \mathrm{~mm}$; agricultural field: $36.9 \mathrm{~mm}$ ). This can be attributed to the presence in the forested area of conifer species, the growing season of which begins earlier. Nevertheless, the value of albedo is also smaller in the case of the forested area; consequently the absorbed energy is higher, which can be manifested in higher evapotranspiration.

By contrast, each study area expresses greater or lesser underestimation in the growing season (i.e., the calculated $\mathrm{PET}_{\mathrm{H}}$ shows lower values than the measured values), particularly toward the higher values (Fig. 1). The largest underestimation occurred in the agricultural field during the growing season. However, the measured PET (PET CREMAP/LYS $_{\text {) }}$ removes the underestimations during the calibration of the calculated PET $\left(\mathrm{PET}_{\mathrm{H}}\right)$ because the measured PET was accepted as real data. Therefore, the measured PET (PET CREMAP/LYS) makes the calculated PET $\left(\mathrm{PET}_{\mathrm{H}}\right)$ surface dependent.

\section{Calibration of the actual \\ evapotranspiration}

As the second step of the calibration, the calculated actual evapotranspiration $\left(\mathrm{ET}_{\mathrm{M}}\right)$ has been calibrated based on the parame-

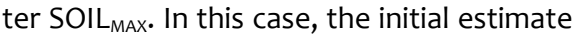
of SOIL $\mathrm{LAX}_{\text {MAX }}$ had to be adjusted in order to reach a maximal correlation between $\mathrm{ET}_{\mathrm{yy}} \mathrm{l}$ $\mathrm{ET}_{\text {CREMAP }}$ and $\mathrm{ET}_{\mathrm{M}}$. To achieve this maximum correlation, the "optim" function of the mentioned R software was applied. Using

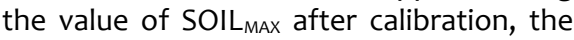
vertical extent of the root zone (and the maximum depth of tilth) can be calculated
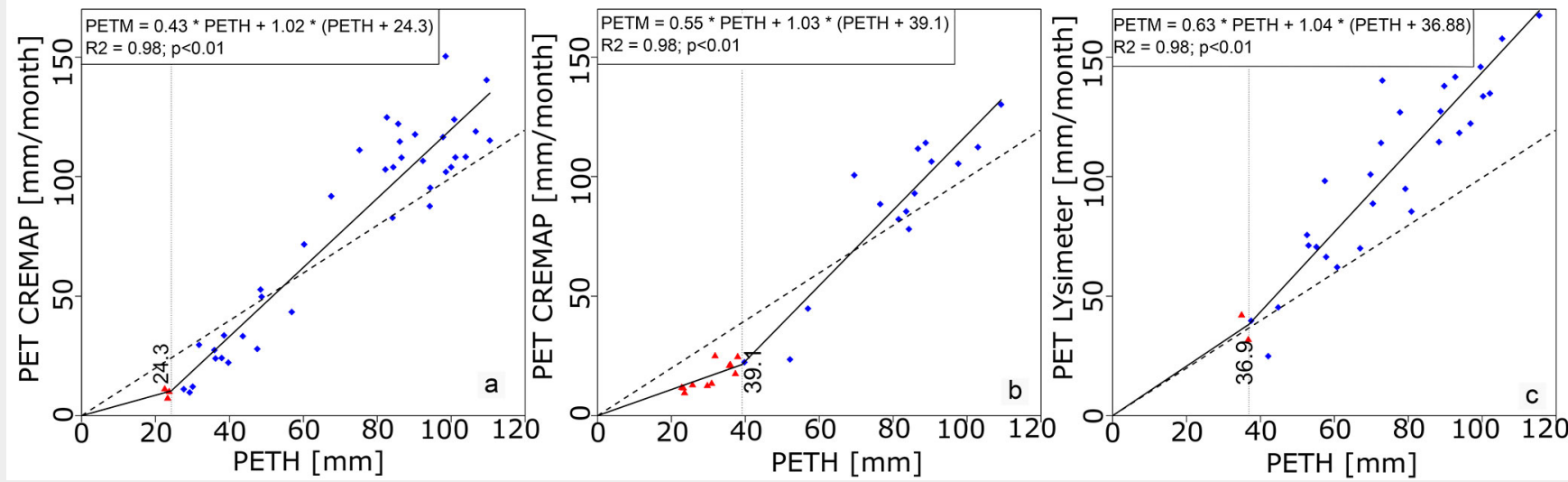

Fig. 1 - Relationship between PET $T_{\text {CREMAP }} / \mathrm{PET}_{\text {LYSIMETER }}$ and PET in growing and dormant seasons with a 1:1 line (dotted), at forested area (a), at mixed parcel (b), at agricultural field (c) obtained after the calibration of $\mathrm{PET}_{\mathrm{H}}$. The red triangles represent the values of the dormancy period, while blue dots represent the values of the growing season. The vertical dotted line is the separation of the two different vegetative states. 

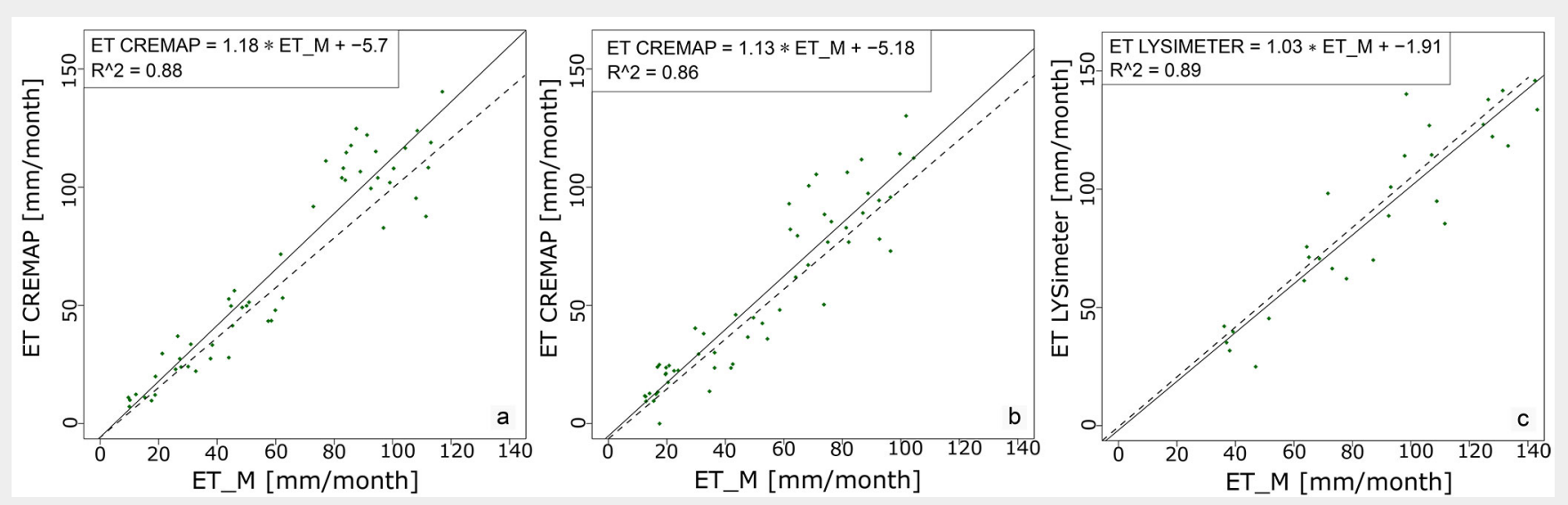

Fig. 2 - Relationship between the calculated $\mathrm{ET}_{\mathrm{M}}$ and the measured $\mathrm{ET}_{\text {CREMAP }}$ or $\mathrm{ET}_{\text {LYSIMETER }}$ obtained after model calibration in each study area. (a): forested area; (b): mixed parcel; (c): agricultural field.
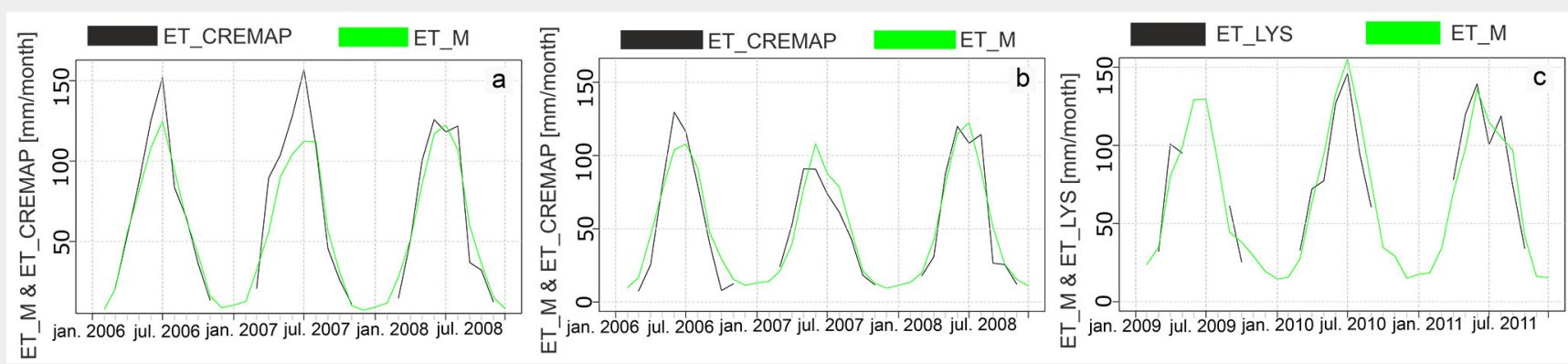

Fig. 3 - Comparison of the time series of measured $\mathrm{ET}_{\text {CREMAP }}$ or $\mathrm{ET}_{\mathrm{LYS}}$ and calculated $\mathrm{ET}_{\mathrm{M}}$ values obtained after the validation step in each study area. (a): forested area; (b): mixed parcel; (c): agricultural field.

using soil texture data.

The Nash-Sutcliffe coefficient ( $\left.R^{2}{ }_{\mathrm{NS}}\right)$ of the calibrated models were $0.85,0.88$ and 0.88 for the forested area, mixed parcel and agricultural field, respectively, while the coefficients of determination $\mathrm{R}^{2}$ were 0.88 , $0.86,0.89$, respectively (Fig. 2). Consequently, the most accurate calibrated model was for the agricultural field, likely due to the homogeneous and permanent grass cover, which maintains reference conditions. Nonetheless, there were no significant differences between the calibrated models. Accordingly, our model calibration and the performance of our model are reliable.

\section{Results of validation}

Fig. 3 displays the results of the model validation. The calculated $\mathrm{ET}_{\mathrm{M}}$ using the weather data over the validation period (forested area and mixed parcel: 20062008; agricultural field: 2009-2011) showed good accordance with the measured data ( $\left.E T_{\text {LYS }} / E_{\text {CREMAP }}\right)$. The $R^{2}$ NS values were equal with 0.88 (forested area); 0.89 (mixed parcel); 0.85 (agricultural field), therefore each model was accurate.

Greater difference was found between the measured $\mathrm{ET}_{\text {CREMAP }}$ and the calculated $\mathrm{ET}_{\mathrm{M}}$ values in the forested area, particularly in the summer of 2007 (Fig. 3a). The greater difference is likely due to interception which is not included in the model.
Nevertheless, there were larger sums of light precipitation at the forested area in the months of June and July in 2007, which results in higher interception. Therefore, there is an underestimation of the calculated actual evapotranspiration that causes the higher difference, particularly at the forested area in July 2007.

Although the curves of the agricultural field model fit each other the best visually, this model performed the "worst" regarding the Nash-Sutcliffe coefficient, due to the data loss caused by a thunderstorm in the summer of 2009.

\section{Results of the model adjustments}

As mentioned above, the model was recalibrated for each study area using all available data as a basis for the projection procedure. The parameters of the re-cali-

Tab. 1 - Results of the adjusted, re-calibrated model parameters in the study sites.

\begin{tabular}{|c|c|c|c|c|c|}
\hline \multirow{2}{*}{$\begin{array}{l}\text { Study } \\
\text { sites }\end{array}$} & \multicolumn{2}{|c|}{ Re-calibrated PET parameter } & \multicolumn{3}{|c|}{ Re-calibrated AET parameter } \\
\hline & Model & $\mathbf{R}^{2}$ & Model & $\mathbf{R}^{2}$ & $\mathbf{R}^{2}{ }_{\mathrm{NS}}$ \\
\hline $\begin{array}{l}\text { Forested } \\
\text { area }\end{array}$ & $\begin{aligned} \mathrm{PET}_{\mathrm{M}} & =0.42 \cdot \mathrm{PET}_{\mathrm{H}} \\
& +1.09 \cdot\left(\mathrm{PET}_{\mathrm{H}}-26.04\right)\end{aligned}$ & 0.98 & $\mathrm{ET}_{\text {CREMAP }}=1.14 \cdot \mathrm{ET}_{M}-4.79$ & 0.89 & 0.88 \\
\hline $\begin{array}{l}\text { Mixed } \\
\text { parcel }\end{array}$ & $\begin{array}{l}\mathrm{PET}_{\mathrm{M}}=0.50 \cdot \mathrm{PET}_{\mathrm{H}} \\
\quad+1.05 \cdot\left(\mathrm{PET}_{\mathrm{H}}-37.13\right)\end{array}$ & 0.98 & $\mathrm{ET}_{\mathrm{CREMAP}}=1.08 \cdot \mathrm{ET}_{\mathrm{M}}-4.31$ & 0.87 & 0.88 \\
\hline $\begin{array}{l}\text { Agricultural } \\
\text { field }\end{array}$ & $\begin{array}{l}\mathrm{PET}_{M}=0.54 \cdot \mathrm{PET}_{H} \\
\quad+1.04 \cdot\left(\mathrm{PET}_{H}-36.79\right)\end{array}$ & 0.98 & $E T_{\text {LYS }}=1.04 \cdot \mathrm{ET}_{\mathrm{M}}-2.36$ & 0.88 & 0.88 \\
\hline
\end{tabular}

brated models used in the projection phase are reported in Tab. 1. After comparison of the adjusted, re-calibrated, and the calibrated parameters, the $\mathrm{R}^{2}$ and $\mathrm{R}^{2} \mathrm{NS}$ values resulted more satisfactory in the case of recalibrated models, although no significant differences between them were detected.

Tab. 2 displays the SOIL $\mathrm{LAX}_{\text {Max }}$ values after recalibration with the calculated rooting depth as well as soil types with their field capacity and permanent wilting point. Much higher soil-water storage capacity (SOIL $L_{\text {MAX }}$ ) was calculated for the forested area due to the presence of trees (tree cover is almost $100 \%$ in the area), which also means higher rooting depth and larger soil water reservoir as well. As explained earlier, the mixed parcel can be seen as a the agricultural field because of the prestransition between the forested area and 
Tab. 2 - Soil types, values of field capacity, permanent wilting point, re-calibrated $\mathrm{SOIL}_{\text {MAX }}$ and re-calibrated rooting depth in the study areas. Soil types were determined using the available data in the AgroClimate.2 project (forested area) or by soil sampling from borehole (mixed parcel). Field capacity (FC, dimensionless) and permanent wilting point (PWP, dimensionless) values of forested area and mixed parcel were used in accordance with Maidment (1993). (*): see Tab. 3.

\begin{tabular}{lccccc}
\hline Study sites & Soil type & FC & PWP & $\begin{array}{c}\text { SOIL }_{\text {MAx }} \\
(\mathbf{m m})\end{array}$ & $\begin{array}{c}\text { Rooting } \\
\text { depth }(\mathbf{m m})\end{array}$ \\
\hline Forested area & sandy loam & \multirow{2}{*}{0.207} & 0.095 & 502.4 & 4486 \\
\cline { 1 - 4 } Mixed parcel & sandy loam & & & 276.9 & 2472 \\
\hline Agricultural field & sandy loam & $*$ & $*$ & 142.4 & 890 \\
\hline
\end{tabular}

Tab. 3 - Main properties of the soil profile in the lysimeter. (PAW): plant available water; $\left(\mathrm{PAW}_{\mathrm{acc}}\right)$ : PAW accumulated to the bottom of the given layer.

\begin{tabular}{ccccc}
\hline $\begin{array}{c}\text { Depth } \\
(\mathbf{c m})\end{array}$ & $\begin{array}{c}\boldsymbol{\theta}_{\text {fc }} \\
(\text { vol-\%) }\end{array}$ & $\begin{array}{c}\boldsymbol{\theta}_{\text {pwp }} \\
(\text { vol-\%) }\end{array}$ & $\begin{array}{c}\text { PAW } \\
(\text { vol-\%) }\end{array}$ & $\begin{array}{c}\text { PAW acc } \\
(\mathbf{m m})\end{array}$ \\
\hline $0-20$ & 30.1 & 14.9 & 15.2 & 30.4 \\
\hline $20-40$ & 32.7 & 17.2 & 15.5 & 61.4 \\
\hline $40-60$ & 30.4 & 14.7 & 15.7 & 92.8 \\
\hline $60-80$ & 30.2 & 13.5 & 16.7 & 126.2 \\
\hline $80-100$ & 29.7 & 12.3 & 17.4 & 161 \\
\hline $100-140$ & 30.0 & 11.9 & 18.1 & 233.4 \\
\hline $140-250$ & 1.7 & 0.8 & 0.9 & - \\
\hline
\end{tabular}

ence of poplars. Therefore, the $\approx 2.5 \mathrm{~m}$ rooting depth is acceptable (the rooting depth can be determined with the help of the calibrated SOIL $\mathrm{LAx}_{\mathrm{A}}$ and soil sampling results).

We used another method to determine the rooting depth at the agricultural field because $\theta_{\mathrm{fc}}$ and $\theta_{\mathrm{pwp}}$ parameters of the soil texture and plant available water (PAW) were available (Tab. 3 ). The rooting depth $\left(\mathrm{z}_{\mathrm{rz}}\right)$ was $890 \mathrm{~mm}$ for the agricultural field (Tab. 2). The exact value of the rooting depth was determined using iteration between PAW values of 126.2 and $161.0 \mathrm{~mm}$ (Tab. 3).

\section{Results and tendencies of the Regional Climate Models}

The annual temperature means and the annual precipitation sums show an increas- ing tendency for each study site towards the end of $21^{\text {st }}$ century. According to the $\mathrm{RCM}$ projections, the rate of increase of annual temperature in the period 2070/ 2100 (compared to the 1985/2015 reference period) is $1.9^{\circ} \mathrm{C}$ for all the studied areas, while for precipitation the projections are: 68 $\mathrm{mm}$ (forested area); $69 \mathrm{~mm}$ (mixed parcel); $71 \mathrm{~mm}$ (agricultural field). Therefore, the rates of the expected temperature and precipitation increase are equivalent for the three study areas.

The different RCMs used for our projection provide different results, which influence the parameters (outputs) of the water balance. Compared to the averages of RCMs, the model with higher precipitation may indicate higher available water, while the greater temperature may cause greater potential evapotranspiration.

Tab. $4-E_{M}, S_{S O I}$ and SOIL $L_{M}$ operc values ( \pm standard deviation) obtained from the projection at the study areas.

\begin{tabular}{|c|c|c|c|c|c|}
\hline $\begin{array}{l}\text { Study } \\
\text { sites }\end{array}$ & Parameters & $1985 / 2015$ & $2015 / 2045$ & $2045 / 2075$ & $2070 / 2100$ \\
\hline \multirow{3}{*}{ 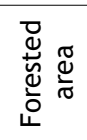 } & $\mathrm{ET}_{\mathrm{M}}\left(\mathrm{mm}\right.$ month $\left.^{-1}\right)$ & $48 \pm 38$ & $48 \pm 37$ & $51 \pm 39$ & $52 \pm 40$ \\
\hline & $\mathrm{SOIL}_{M}(\mathrm{~mm})$ & $417 \pm 92$ & $416 \pm 74$ & $415 \pm 76$ & $394 \pm 86$ \\
\hline & $\mathrm{SOIL}_{\mathrm{M}_{1} 10 \mathrm{Perc}}(\mathrm{mm})$ & $208 \pm 59$ & $270 \pm 32$ & $271 \pm 25$ & $234 \pm 37$ \\
\hline \multirow{3}{*}{ 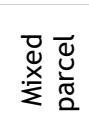 } & $\mathrm{ET}_{M}\left(\mathrm{~mm} \mathrm{month}^{-1}\right)$ & $43 \pm 35$ & $43 \pm 33$ & $45 \pm 35$ & $46 \pm 35$ \\
\hline & $\mathrm{SOIL}_{M}(\mathrm{~mm})$ & $215 \pm 57$ & $210 \pm 61$ & $211 \pm 63$ & $199 \pm 69$ \\
\hline & $\mathrm{SOIL}_{\mathrm{M}_{1} \text { OPerc }}(\mathrm{mm})$ & $109 \pm 20$ & $96 \pm 15$ & $96 \pm 14$ & $77 \pm 21$ \\
\hline \multirow{3}{*}{ 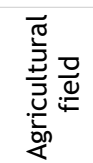 } & $\mathrm{ET}_{M}\left(\mathrm{~mm} \mathrm{month}^{-1}\right)$ & $49 \pm 34$ & $49 \pm 33$ & $52 \pm 34$ & $53 \pm 35$ \\
\hline & $\mathrm{SOIL}_{M}(\mathrm{~mm})$ & $58 \pm 40$ & $65 \pm 43$ & $66 \pm 44$ & $67 \pm 48$ \\
\hline & $\mathrm{SOIL}_{\mathrm{M}_{1} 10 \mathrm{Perc}}(\mathrm{mm})$ & $8 \pm 3$ & $7 \pm 2$ & $6 \pm 3$ & $5 \pm 3$ \\
\hline
\end{tabular}

Results of the projections for the $21^{\text {st }}$ century

Tab. 4 shows the results of RCM projections for the 4 investigation period. The mean values of actual evapotranspiration $\left(E T_{M}\right)$ will slightly increase at each study site by the end of the $21^{\text {st }}$ century. However, the large standard deviations of $\mathrm{ET}_{M}$ indicate a great uncertainty that is inherent to modelled data, particularly as four different RCMs were used. By the end of the $21^{\text {st }}$ century, the anticipated rates of increase are $+8 \%\left(+4 \mathrm{~mm} \mathrm{month}^{-1}\right)$ at the forested area, $+8 \%\left(+4 \mathrm{~mm}^{m^{2}}\right.$ th $\left.^{-1}\right)$ at the agricultural field and $+7 \%\left(+3 \mathrm{~mm} \mathrm{month}^{-1}\right)$ at the mixed parcel (Tab. 4). The highest absolute values of $\mathrm{ET}_{M}$ were obtained for the agricultural field, since RCMs project the highest temperature for the grass covered surface among the study areas. During the 2015/ 2045 period the $\mathrm{ET}_{\mathrm{M}}$ values stagnate, reflecting the decrease in the projected temperatures $\left(-0.2,-0.1\right.$ and $0{ }^{\circ} \mathrm{C}$ for the forested area, mixed parcel, and agricultural field, respectively). Conversely, there is a typical increasing trend in the second half of the century at each study area (the most considerable upward rate appears in the 2045/2075 period), since precipitation and temperature increases simultaneously (i.e., there is available water for the evapotranspiration process).

Contrary to the tendencies of $\mathrm{ET}_{M}$ values, there are larger differences in the mean values of soil moisture ( $\left.\mathrm{SOIL}_{M}\right)$ among the study sites (Tab. 4), because of the larger differences in the SOIL MAX values. The forested area has the highest and the agricultural field has the lowest soil moisture mean values. Compared to the 1985/2015 period, we found a decrease for the forested area $(-6 \% ;-23 \mathrm{~mm})$ and the mixed parcel $(-7 \% ;-16 \mathrm{~mm})$, but an increase for the agricultural field $(+12 \% ;+9 \mathrm{~mm})$ by the end of the $21^{\text {st }}$ century. These increases could be due to precipitation as a significant and continuous increasing is expected for the second part of the $21^{\text {st }}$ century. Nevertheless, the shape of the graph for $\mathrm{ET}_{M}$ monthly values at the agricultural field (Fig. 4) is flatter, i.e., lower $\mathrm{ET}_{\mathrm{M}}$ peak values for the summer period (though higher for annual means) that may lead to increasing $\mathrm{SOIL}_{M}$ values.

With regard to plant water uptake, the minimum soil moisture were calculated as $10^{\text {th }}$ percentile minimum values $\left(\mathrm{SOIL}_{\mathrm{M}_{1} \text { 10Perc }}\right.$ - Tab. 4). The percentile analysis offers key information regarding water stress as it represents different results than $\mathrm{SOIL}_{M}$ values. Comparing the 2070/2100 period to the 1985/2015 reference period, the forested area shows increasing SOIL $_{\mathrm{M}_{10} \mathrm{Perc}} \mathrm{val}$ ues $(+11 \% ;+26 \mathrm{~mm})$ by the end of $21^{\text {st }}$ century, while there is a significant decreasing tendency at the mixed parcel $(-29 \% ;-32$ $\mathrm{mm})$ and the agricultural field $(-37 \% ;-3$ $\mathrm{mm})$. The predicted increase at the forested area is likely due to the deep root zone $(\sim 4.5 \mathrm{~m})$ which allows a high SOIL $_{\text {MAX }}$, i.e., a greater amount of available water for 

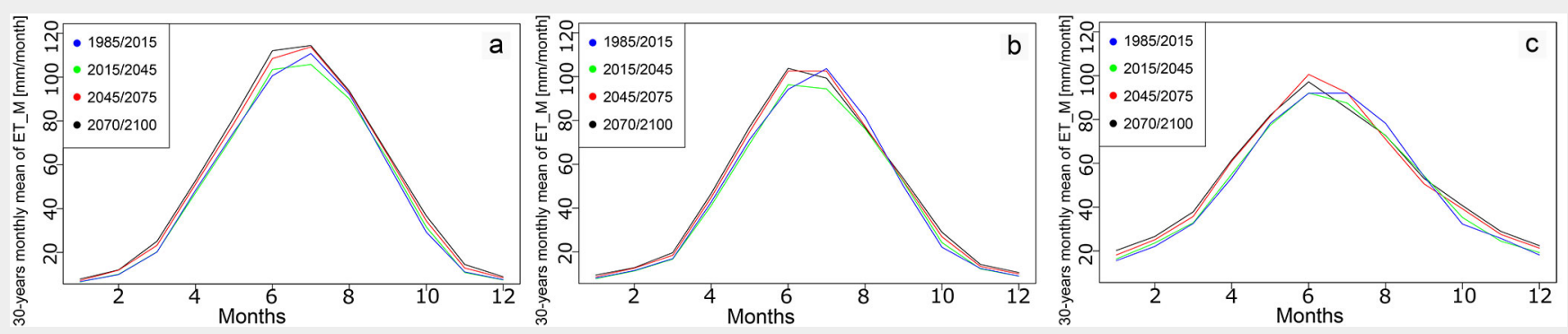

Fig. 4 - Monthly values of $\mathrm{ET}_{\mathrm{M}}$ for the study areas for the investigated 30-year means. (a): forested area; (b): mixed parcel; (c): agricultural field.
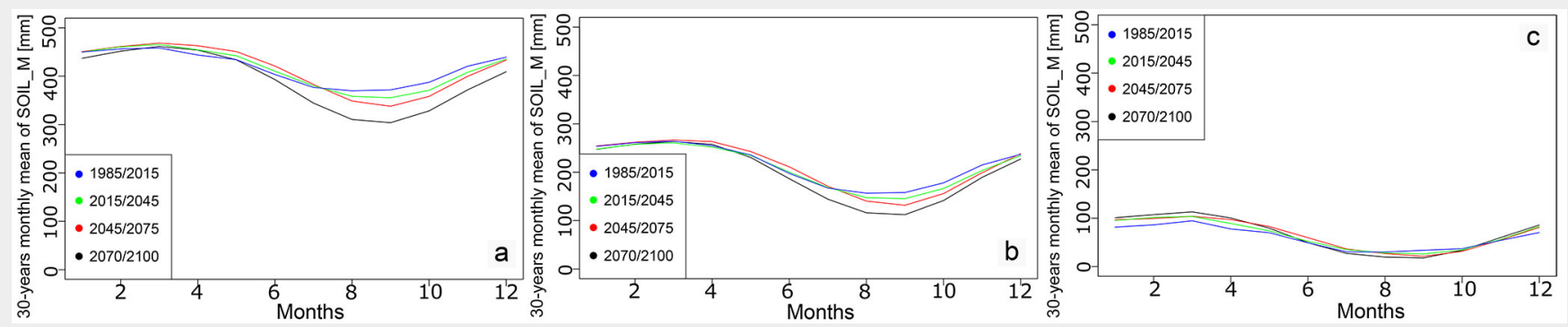

Fig. 5 - Monthly values of SOIL ${ }_{M}$ for the study areas for the investigated 30-year means. (a): forested area; (b): mixed parcel; (c): agricultural field.

the plants. It should be noted that $\mathrm{SOIL}_{\mathrm{M}_{1} \text { 10Perc }}$ values of the agricultural field are really close to zero (Tab. 4) due to the lowest vertical extent of the root zone and the lowest SOIL $\mathrm{L}_{\text {MAX }}$ value among the three study sites. At the forested area, a significant increase $(+23 \% ;+62 \mathrm{~mm})$ appears in the period $2015 / 2045$, constancy $(+1 \% ;+1$ $\mathrm{mm}$ ) occurs in the period 2045/2075, but a significant decrease $(-16 \% ;-37 \mathrm{~mm})$ is expected in the period $2070 / 2100$. Furthermore, nearly equal drop rates occur at the mixed parcel $(-12 \% ;-13 \mathrm{~mm})$ and the agricultural field $(-13 \%$; $-1 \mathrm{~mm})$ in the $2015 / 2045$ period. Stagnancy was found in the 2045/ 2075 period at the mixed parcel (0\%; $0 \mathrm{~mm})$ and a decrease at the agricultural field $(-14 \% ;-1 \mathrm{~mm})$, while a downward trend can be observed at the end of the $21^{\text {st }}$ century at the mixed parcel $(-29 \% ;-19 \mathrm{~mm})$. However, nearly equal decreasing rates are expected at the agricultural field $(-17 \% ;-1$ $\mathrm{mm})$. The reason underlying the stagnancy in the middle of the $21^{\text {st }}$ century (2045/ 2075) could be the simultaneous increase of temperature and precipitation, which, therefore, compensates for the decreasing SOIL $_{M_{1} 10 \text { Perc. }}$ Moreover, in the period 2070/ 2100 temperatures still shows a significant increase, while the increase of precipitation is less pronounced. Consequently, a remarkable decrease in SOIL $_{M_{10} \text { Perc }}$ is expected in each study area. However, considering the uncertainty of the projected precipitation of the RCMs, a clear explanation cannot be given.

The previous analyses are based on annual mean values for the four 30-year-long investigation periods. These analyses, however, do not indicate the monthly development of output parameters of the models.
Hence, a future research study that focuses on the 30-year monthly mean of $\mathrm{ET}_{\mathrm{M}}$ plus $\mathrm{SOIL}_{M}$ is required.

Fig. 4 emphasizes the changes in the 30year monthly means of $\mathrm{ET}_{\mathrm{M}}$, while Fig. 5 highlights the seasonal periodicity of SOIL ${ }_{M}$. Considering the 30-year monthly mean of $\mathrm{ET}_{\mathrm{M}}$, the greatest values at each study site occur in June and July, whereas the smallest in December and January. This can be attributed to the greater transpiration in the summer period, which can generates higher evapotranspiration values. In addition, a quick increase reflects the beginning of the biological activity of plants in April (Fig. 4). The values of $\mathrm{ET}_{M}$ generally increase towards the end of $21^{\text {st }}$ century, particularly in the summer period (10-15 mm month ${ }^{-1}$ ), i.e., $10-13 \%$ significantly upward rates; this could be due to the enhanced evapotranspiration constraint by the end of the $21^{\text {st }}$ century due to the expected rising temperatures in the summer period. However, in the case of agricultural field, the largest values appear in the 2045/2075 period. Moreover, the greatest differences occur among the investigation periods in summer as well. Similar to the annual averages, the $1985 / 2015$ period

Tab. 5 - The values of relative extractable water (REW) in the $21^{\text {st }}$ century for the study areas. Each 30 -year period contains 360 months. The value 0.83 indicates that $83 \%$ of the 360 monthly REW values do not drop under the threshold of $50 \% \mathrm{SOIL}_{\text {MAX. }}$.

\begin{tabular}{lcccc}
\hline Study area & $1985 / 2015$ & $2015 / 45$ & $2045 / 75$ & $2070 / 2100$ \\
\hline Forested area & 0.83 & 0.83 & 0.82 & 0.78 \\
\hline Mixed parcel & 0.78 & 0.76 & 0.76 & 0.71 \\
\hline Agricultural field & 0.42 & 0.46 & 0.46 & 0.46 \\
\hline
\end{tabular}

shows larger $\mathrm{ET}_{\mathrm{M}}$ values than the period 2015/2045. Although the agricultural field has the highest values of $\mathrm{ET}_{M}$ regarding annual averages, the calculation of 30-year monthly mean of $\mathrm{ET}_{\mathrm{M}}$ reveals that the forested area and the mixed parcel have the highest $\mathrm{ET}_{\mathrm{M}}$ values in the summer period. Hence, the shape of the curves of the agricultural field (Fig. 4C) is flatter than the other two areas, with higher values in winter, but lower values in summer. These higher values at the agricultural field during dormancy are likely related to the earlier start of the growing season in areas with a grass surface. In addition, unlike forests, grass can transpire even in winter periods (as reflected by the higher values in winter at the agricultural field - Fig. 4C), while deciduous species at the forested area are leafless in winter. The maximums of $\mathrm{ET}_{\mathrm{M}}$ in summer were 115,105 and $100 \mathrm{~mm}$ month-1 $^{-1}$ for the forested area, mixed parcel, and agricultural field, respectively. These values reflect the higher leaf area index of forests, leading to higher evaporative surface in the growing seasons.

The 30-year monthly mean of $\mathrm{SOIL}_{M}$ shows a slight increase from January to March, when the soil is saturated and the 
values of $\mathrm{SOIL}_{M}$ are the closest to the water storage capacity (SOIL $\mathrm{SAX}_{\text {MA }}$ ). From March to September, a decrease of soil moisture occurs due to the rising evapotranspiration. Consequently, the minimum values occur in early autumn (September) in each study area (Fig. 5). The increase observed in September is caused by the transition to the dormant season.

When the three study sites are compared, the most significant differences appear for the 30-year monthly mean of $\mathrm{SOIL}_{M}$ values rather than at the $\mathrm{ET}_{M}$ values. The highest $\mathrm{SOIL}_{M}$ and $\mathrm{ET}_{M}$ values are observed at the forested area. The forested area and mixed parcel show equal annual fluctuation $(\sim 150$ $\mathrm{mm}$ ), whereas the lowest values of $\mathrm{ET}_{\mathrm{M}}$ and $\mathrm{SOIL}_{M}$ and smallest fluctuation of $\mathrm{SOIL}_{M}(\sim 90 \mathrm{~mm})$ are found at the agricultural field. The rates of the annual soil moisture fluctuations and soil moisture storage capacity (SOIL $\mathrm{LAX}_{\text {MX }}$ ) are lowest at the forested area (30\%) but highest at the agricultural field (63\%). Fig. 5 confirms that the highest $\mathrm{SOIL}_{M}$ values appear at the beginning of the investigation period, but lowest values are expected at the end of the $21^{\text {st }}$ century.

Based on the above evidence, the water stress probability may increase towards the end of the $21^{\text {st }}$ century.

\section{Results of the water stress analyses}

Tab. 5 summarises the mean values of REW (eqn. 8) derived from the four applied RCMs for each investigation period. A decrease of REW values towards the end of the $21^{\text {st }}$ century is predicted at the forested area and the mixed parcel. However, the average REW values do not approach the $50 \%$ threshold of $\mathrm{SOIL}_{\text {MAX }}$ at both sites. Average REW values for the forested area range from $83 \%$ to $78 \%$ (i.e., water stress is predicted in 61 to 79 out of the 360 months considered), while for the mixed parcel range from $78 \%$ to $71 \%$ (79 to 104 months out of 360). REW values at the agricultural field decrease below the 50\% threshold more frequently, i.e., water stress is likely to occur only at the agricultural field (Tab. 5). Indeed, there is an increase of REW values at the agricultural field from $42 \%$ (in the $1985 / 2015$ observational based period) to $46 \%$, which remains constant during the $21^{\text {st }}$ century as a result of the similar increase in temperature and precipitation.

Based on the above evidences, significant water stress is expected in the future at the agricultural field area, due to the relatively small SOIL MAX $_{\text {value and small rooting }}$ depth detected.

\section{Discussion}

In this study, a Thornthwaite-type water balance model was adapted and applied to assess the future development of evapotranspiration and soil moisture in the western part of the Carpathian Basin.

Our study indicates an increasing tendency of actual evapotranspiration across the study areas towards the end of the $21^{\text {st }}$ century, with high annual fluctuation and greater peaks for summer. The monthly average values of soil moisture, however, show no clear trend or a weak increase, whereas the lower $10^{\text {th }}$ percentile minimums show a significant decrease and greater annual fluctuation (particularly in the early autumn) towards the end of the $21^{\text {st }}$ century. The results showed that significant plant water stress is expected to occur only at the agricultural field.

In this study a relatively straightforward model approach was applied to regional conditions, though further research should refine our analysis, for example by considering crop characteristics, different soil, or land use changes. According to Bormann et al. (2007) land use change (in addition to climate change) can have a strong impact on soil water balance, which they evaluated through the comparison of several hydrological catchment models. As stated by Bormann et al. (2007), changes in soil properties (as a part of land use change scenario) should be considered to attain highly-reliable water balance models.

Granier et al. (1999) established a daily lumped water balance model for forest stands with the aim of quantifying drought intensity and duration in different regions of France from 1951 to 1991. Compared to their results, we had relatively deep soil values (rooting depth of 4.5, 2.4, and $0.9 \mathrm{~m}$ for forested area, mixed parcel, and agricultural field, respectively). However, in this study only one soil layer was considered, as not enough information about soil characteristics was available (Granier et al. 1999). As a consequence of the deep soil

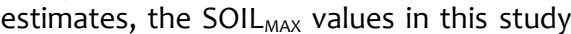
(502.4, 276.9 and $142.4 \mathrm{~mm}$ for forested area, mixed parcel and agricultural field, respectively) are much higher than those reported in Granier et al. (1999 - 180, 185 and $72 \mathrm{~mm}$ for coniferous and broadleaved stands on deep soil, and for broadleaved stands on shallow soil, respectively). Unlike these authors, we used a 0.5 (50\%) value instead of $0.4(40 \%)$ as REW threshold, mostly because we considered three different kinds of surface cover. Moreover, Allen et al. (1998) advised a general threshold of 0.5 in the case of crops.

The monthly average of the modeled relative extractable water (REW) for the crop field showed an increasing trend (from $42 \%$ to $46 \%$ ) towards the end of the $21^{\text {st }}$ century, and values below the $50 \%$ threshold are expected to occur frequently. In contrast, REW values for forested area and mixed parcel do not approach such threshold (78\% and $71 \%$, respectively). According to Granier et al. (1999), REW values did not lower below the 0.4 threshold in the wettest years in deep soils even in late summer (August and September), but can drop below such thresholds during the driest years.

Remrová \& Císlerová (2010) studied the impacts of climate change on the water balance of a grass-covered experimental catchment in the Czech Republic, finding that the vertical extent of the root zone was lower and the soil profile shallower (75 $\mathrm{cm}$ ) compared to our agricultural field (140 $\mathrm{cm})$. Nonetheless, they did not predict significant water stress (only 6 days in the summer of 2095), likely because their study area is more humid (1200 mm annual average precipitation) and cooler $\left(8.1^{\circ} \mathrm{C}\right.$ annual air temperature). Moreover, they used a more pessimistic projection, particularly at the end of the $21^{\text {st }}$ century (climate scenario $\mathrm{A} 2$, with a single $\mathrm{RCM}$ over the period 2071-2100), than those used in this study (scenario $\mathrm{A} 1 \mathrm{~B}$, with $4 \mathrm{RCMs}$ over the whole $21^{\text {st }}$ century). Our annual AET increased over the period considered from 594 to $628 \mathrm{~mm}$ year $^{-1}(+5 \%)$ in the case of agricultural field, which is lower than the $+12 \%$ (from 400 to $450 \mathrm{~mm}$ ) reported by Remrová \& Císlerová (2010). Furthermore, the absolute values of actual evapotranspiration (AET) in their study are lower, due to the aforementioned temperature difference.

Lutz et al. (2010) developed a water balance model using a modified Thornthwaitetype method (Dingman 2002) on monthly step, with Hamon PET (Hamon 1963) approach, aimed at predicting the effect of changes in soil water balance on species ranges by mid-century in the Yosemite $\mathrm{Na}$ tional Park (USA). They predicted an increase of $10 \%$ in AET across all plots over the 2020-2049 period, while in this study we found a substantial steadiness of AET values ( $572 \mathrm{~mm}$ year ${ }^{-1}$ ) in the forested area. Similar to Lutz et al. (2010) results, the AET peaks occur in July, though we found a lower value (115 mm month ${ }^{-1}$ ). In our study sites, the water deficit (PET-AET) at the forested area shifts from $88 \mathrm{~mm}$ to $73 \mathrm{~mm}$ $(-21 \%)$ over the period $2020-2049$, while in their study the projected increase in deficit between the present and the future (20202049) was $23 \%$ across all plots, as a consequence of the increased temperature plus PET and decreased snowpack.

Regarding the annual tendency of AET rates, our results agree with those reported by Keables \& Mehta (2010) who used a monthly step Thornthwaite water balance approach in Kansas (USA). The AET rates in their study are small during the winter in response to lower temperatures, but increase in the spring with temperature and available water. AET peaks in July with 151-175 mm month ${ }^{-1}$ as the highest values of their study area. In our case, June basically has the highest AET values with 100-115 mm month-1. Similar to their results, the potential water deficit is predicted in the summer period (highest values in July and August).

Gulyás et al. (2015) utilized a water balance model after Thornthwaite \& Mather (1955) to assess the water stress in a protected Pinus Sylvestris forest near Fenyőfö, Györ-Moson-Sopron county in Hungary. They calculated REW values using the soil moisture output data, which was esti- 
mated by the Thornthwaite-type water balance model after Granier et al. (1999) as well. They reported that REW strongly decreased in the period 1961-2013. During the years of 1990-1991, 2001-2004, and 20112012, a huge water deficit occurred in the soil. The most significant water decrease was found at the beginning of the 1990s with extreme summer drought, and negative effects on the investigated forest. In our study, average REW values for the forested area showed a decreasing tendency over a different period (1985-2100), though they never approached to the $50 \%$ threshold. It should be noted that Gulyás et al. (2015) applied $40 \%$ as a threshold.

Nistor et al. (2016) evaluated the annual and seasonal crop evapotranspiration of the Carpathian Region from 1961 to 2010 using two datasets from 1961-1990 and from 1990 to 2010. They reported the same trends as in our study, with a rise in temperature and evapotranspiration values between their investigation periods. They found that absolute changes of annual crop evapotranspiration is insignificant, with a maximum value of $49 \mathrm{~mm}$ (0.06\%) between 1961-1990 and 1991-2010.

Csáki et al. (2020) presented a long-term, spatially distributed, Budyko-type climaterunoff model tested on the Zala River Basin (an essential runoff contributing region to Lake Balaton in Hungary). In their study, averaged long-term annual evapotranspiration and runoff were projected for the $21^{\text {st }}$ century using precipitation and temperature as input data from 12 RCMs (A1B scenario). According to their projections, the long-term mean annual evapotranspiration may increase by $4.4 \%$ at the end of the $21^{\text {st }}$ century (2071-2100) relative to their reference period (1981-2010), while in our case a $7-8 \%$ increase rate has been predicted (2070-2100 relative to the 1985-2015 period), but in a monthly step.

Climate simulations for the Rhine-Meuse drainage area in central-western Europe were carried out by Van Der Linden et al. (2019) with a high spatial resolution (25 $\mathrm{km}$ ) GMC model (EC-Earth V2.3 model) to study two model run over 30-year periods (2094-2098 vs. 2002-2006 as reference period) under low-to-moderate greenhouse gas forcing (RCP4.5). Large annual cycles of soil moisture with minimum values in September $(860 \mathrm{~mm})$ were indicated, which is higher compared to our study (300, 150 and $40 \mathrm{~mm}$ for forested area, mixed parcel, and agricultural field, respectively). Their model projections correspondingly result in soil drought during the growing season at the end of $21^{\text {st }}$ century. Such difference could be attributed to the reduction of precipitation with soil moisture depletion at an average of $90 \mathrm{~mm}$, while in our study we found 80,70 and 20 $\mathrm{mm}$ for forested area, mixed parcel, and agricultural field, respectively. According to Van Der Linden et al. (2019), the values of evapotranspiration may significantly increase by the end of $21^{\text {st }}$ century, particu- larly in the summer period with $15 \mathrm{~mm}$ month $^{-1}(+12 \%)$. Our results show similar upward rates (10-13\%) in our study areas, with 10-15 mm month ${ }^{-1}$.

\section{Conclusion}

In this study, a Thornthwaite-type water balance model was applied to assess the impact of climate change on water balance components in a natural forested area, a mixed parcel, and an agricultural field in the western Carpathian Basin.

The main advantage of the developed model is the low amount of input data required (temperature and precipitation). This allows the model to be easily applied to other places where measured data are available for calibration/validation. This model system ensures fast impact analysis of climate change on evapotranspiration and soil water storage, along with the calculation of water stress parameters. Moreover, the model requires a significantly lower amount of work for input data preprocessing and baseline investigations than more complex models.

Based on standard future climate scenarios, an increase in $E T_{M}$ is expected in future decades, with a remarkable shift predicted for $\mathrm{SOIL}_{M}$, indicating that less soil water will be available for plant growth during summer months in the studied region, and confirming the evidences reported by studies using similar methods (Lutz et al. 2010, Var Der Linden et al. 2019, Csáki et al. 2020). In the case of the forested area considered, a lower water stress for plants is expected to occur compared to the other two sites (mixed parcel and agricultural field) due to the larger soil moisture reservoir of forest stands. Nonetheless, critical periods of water shortage could lead to catastrophic effects on Carpathian forested areas, the restoration of which is much more difficult than that of crop fields.

\section{List of abbreviations}

AET: actual evapotranspiration ( $\mathrm{mm}$ ); CREMAP: Calibration-Free Evapotranspiration Mapping; D: daylength (hour); $\mathrm{e}_{\mathrm{m}}^{*}$ :saturation vapor pressure $(\mathrm{kPa})$; $\mathrm{ET}_{\text {CREMAP: }}$ : remote-sensing based actual evapotranspiration (mm); $\mathrm{ET}_{\text {LysIMETER }}$ : actual evapotranspiration values measured by weighinglysimeter $(\mathrm{mm}) \mathrm{ET}_{\mathrm{M}}$ : monthly actual evapotranspiration $\left(\mathrm{mm} \cdot\right.$ month $\left.^{-1}\right)$ : GCM: general circulation model; PAW: plant available water $(\mathrm{mm})$; PET: potential evapotranspiration (mm); PET CREMAP: remote-sensing PET based on actual evapotranspiration at wellwatered conditions (mm); PET LYSIMETER: actual evapotranspiration values measured by weighing-lysimeter at well-watered conditions (mm); $\mathrm{PET}_{\mathrm{H}}$ : Hamon type potential evapotranspiration (mm); $\mathrm{PET}_{\mathrm{M}}$ : calibrated monthly potential evapotranspiration $(\mathrm{mm}) ; \mathrm{P}_{\mathrm{M}}$ : monthly summed precipitation $(\mathrm{mm}) ; \mathrm{R}^{2}$ : coefficient of determination (dimensionless); RCM: regional climate model; REW: Relative Extractable Water (dimensionless); ${ }^{2}{ }_{\text {Ns: }}$ : Nash-Sutcliffe coeffi- cients (dimensionless); $\mathrm{SOIL}_{\mathrm{M}}$ : monthly soil moisture (mm); SOIL ${ }_{\text {MAX }}$ : soil-water storage capacity $(\mathrm{mm})$; SOIL $\mathrm{L}_{\mathrm{M}_{1} \text { operc }}: 10^{\text {th }}$ percentile soil moisture minimum values $(\mathrm{mm}) ; \mathrm{T}_{\mathrm{M}}$ : monthly summed temperature $\left({ }^{\circ} \mathrm{C}\right) ; \mathrm{z}_{\mathrm{rz}}$ : rooting depth (vertical extent of root zone, $\mathrm{mm}) ; \Delta \mathrm{W}_{\text {lys }}$ : daily change of soil water mass $\left(\mathrm{mm}\right.$ day $\left.{ }^{-1}\right) ; \Delta \mathrm{w}_{\text {drain }}$ : daily change of drainage water ( $\mathrm{mm}$ day $\left.{ }^{-1}\right) ; \Delta \mathrm{p}_{\mathrm{lys}}$ : daily change of precipitation ( $\mathrm{mm}$ day $\left.{ }^{-1}\right) ; \Delta \mathrm{l}_{\mathrm{lys}}$ : daily change of irrigation ( $\mathrm{mm}$ day $\left.{ }^{-1}\right) ; \Delta \mathrm{ET}_{\text {lys: }}$ : daily change of evapotranspiration ( $\mathrm{mm}$ day $\left.^{-1}\right)$ : $\triangle$ SOIL: decrease in soil storage $(\mathrm{mm}) ; \theta_{\mathrm{fc}}:$ water content at field capacity (dimensionless); $\theta_{\text {pwp }}$ : water content at permanent wilting point (dimensionless).

\section{Acknowledgement}

This work was supported by the project EFOP-3.6.2-16-2017-00018 of the University of Sopron, Hungary. Fundings from the János Bolyai Scholarship of the Hungarian Academy of Sciences and from the Ministry of Agriculture in Hungary are gratefully acknowledged. The authors wish to thank Reinhard Nolz (University of Natural Resources and Life Sciences, Vienna, Austria) for supplying the lysimeter data.

\section{References}

Aber J, Neilson R, Mcnulty S, Lenihan J, Bachelet D, Drapek R (2009). Forest processes and global environmental change: predicting the effects of individual and multiple stressors. BioScience 51: 735-751. - doi: 10.1641/0006-3568(2001)051 [0735:FPAGEC]2.0.CO;2

Allen RG, Pereira LS, Raes D, Smith M (1998). Crop evapotranspiration: guidelines for computing crop water requirements. In: "FAO Irrigation and drainage paper 56". FAO - Food and agriculture organization of the United Nations, Rome, Italy, pp. 3-13. [online] URL: http:// www.scscourt.org/complexcivil/105CV049053/v olume3/172618e_oxAGWAx8.pdf

Baumgartner A, Liebscher HJ (1995). Allgemeine Hydrologie, Quantitative Hydrologie, In: “Lehrbuche der Hydrologie, Band 1" [General Hydrology, Quantitative Hydrology, In: "Textbooks of Hydrology", vol. 1]. Berlin, Stuttgart, Germany, pp. 320-350. [in German]

Bormann H, Breuer L, Graeff T, Huisman J (2007). Analysing the effects of soil properties changes associated with land use changes on the simulated water balance: a comparison of three hydrological catchment models for scenario analysis. Ecological Modelling 209: 29-40. - doi: 10.1016/j.ecolmodel.2007.07.004

Christensen JH, Christensen OB (2007). A summary of the PRUDENCE model projections of changes in European climate by the end of this century, Climatic Change 81: 7-30. - doi: 10.1007/ s10584-006-9210-7

Csáki P, Gyimóthy K, Kalicz P, Szolgay J, Zagyvainé KKA, Gribovszki Z (2020). Multi-model climatic water balance prediction in the Zala River Basin (Hungary) based on a modified Budyko framework. Journal of Hydrology and $\mathrm{Hy}$ dromechanics 68 (2): 200-210. - doi: 10.2478/ johh-2020-0016

Cui Y, Chen X, Gao J, Yan B, Tang G, Hong Y (2018). Global water cycle and remote sensing 
big data: overview, challenge, and opportunities. Big Earth Data 2 (3): 282-297. - doi: 10.1080/ 20964471.2018.1548052

Czimber K (2018). Agroclimate decision support system. Project TÁMOP-4. 2. 2. A-11/1/KONV-0120013 "The impact assessment of projected climate change and adaptation options in the forestry and agricultural sectors". University of West Hungary, Sopron, Hungary. [online] URL: http://agrarklima2.nyme.hu/dtr/index-eng.html Dingman SL (2002). Physical hydrology ( $2^{\text {nd }}$ edn). Prentice Hall, Upper Saddle River, NJ, USA, pp. 646.

Dobor L, Barcza Z, Hlásny T, Havasi A (2013). Creation of the FORESEE database to support climate change related impact studies, In: Proceedings of the "International Scientific Conference for PhD Students". Györ (Hungary) 1920 Mar 2013. University of West Hungary Press, Sopron, Hungary, pp. 1-5.

Dövényi Z (2010). Magyarország kistájainak katasztere - második, átdolgozott és bövített kiadás [Inventory of microregions in Hungary]. Hungarian Academy of Sciences, Geographical Institute, Budapest, Hungary, pp 299, pp. 345347. [in Hungarian]

Granier A, Breda N, Biron P, Villette S (1999). A lumped water balance model to evaluate duration and intensity of drought constraints in forest stands. Ecological Modelling 116 (2-3): 269283. - doi: 10.1016/S0304-3800(98)00205-1

Gulyás K, Bidló A, Horváth A (2015). Estimation of water stress by comparing the Thornthwaite water balance model with a tree ring width analysis. In: Proceedings of the Conference "HydroCarpath 2015, Catchment Processes in Regional Hydrology”. Nyugat-magyarországi Egyetem Kiadó, Sopron (Hungary) 29 Oct 2016, pp. 6. [online] URL: http://publicatio.nyme.hu/ id/eprint/1443

Gálos B, Führer E, Czimber K, Gulyás K, Bidló A, Hänsler A, Jacob D, Mátyás C (2015). Climatic threats determining future adaptive forest management - a case study of Zala County. IDOJÁRÁS, Quarterly Journal of the Hungarian Meteorological Service, vol. 119, no. 4, pp. 425441. [online] URL: http://www.researchgate. net/publication/289619402

Gáspár L, Karoliny M, Tóth C (2017). BCRRA Predicting subgrade soil strength using FWD and meteorological time series data. In: Proceedings of the " $10^{\text {th }}$ International Conference on the Bearing Capacity of Roads, Railways and Airfields (BCRRA 2017)" (Loizos A, Al-Qadi I, Scarpas T eds). Athens (Greece) 28-30 June 2017. Taylor \& Francis Group, London, UK, pp. 2117-2125.

Götz B, Hadatsch S, Kratochvil R, Vabitsch A, Freyer B (2000). Biologische Landwirtschaft im Marchfeld. Potenziale zur Entlastung des Natur- und Landschaftshaushaltes [Organic farming in Marchfeld. Potential for relieving the natural and landscape balance]. Umweltbundesamt GmbH, Vienna, pp. 34-36. [in German] Hamon WR (1963). Computation of direct runoff amounts from storm rainfall. International Association of Scientific Hydrology 63: 52-62. [online] URL: http://hydrologie.org/redbooks/ao6 3/063006.pdf

Hlásny T, Mátyás C, Seidl R, Kulla L, Merganičová K, Trombik J, Dobor L, Barcza Z, Konôpka B
(2014). Climate change increases the drought risk in Central European forests: what are the options for adaptation? Central European Forestry Journal 60: 5-18. - doi: 10.2478/forj-2014-00 01

IPCC (2019). Technical Summary, 2019. In: “Climate Change and Land. An IPCC Special Report on climate change, desertification, land degradation, sustainable land management, food security, and greenhouse gas fluxes in terrestrial ecosystems" (Shukla PR, Skea J, Calvo Buendia E, Masson-Delmotte $\mathrm{V}$, Pörtner $\mathrm{H}-\mathrm{O}$, Roberts DC, Zhai P, Slade R, Connors S, van Diemen R, Ferrat M, Haughey E, Luz S, Neogi S, Pathak M, Petzold J, Portugal Pereira J, Vyas P, Huntley E, Kissick K, Belkacemi M, Malley J. eds). IPCC, Japan, pp. 37-74. [online] URL: http://www. ipcc.ch/srccl/

Keables MJ, Mehta S (2010). A soil water climatology for Kansas. Great Plains Research 20 (2): 229-248. [online] URL: http://www.jstor.org/sta ble/23780298

Keve G, Nováky B (2010). Klímaváltozás hatásának vizsgálata a Bácsbokodi-Kígyós csatorna vízgyüjtöjén Budyko-modell alkalmazásával [Investigation of the impact of climate change in the catchment of the Bácsbokodi-Kígyós canal using the Budyko model]. In: "A Magyar Hidrológiai Társaság XXVIII, Országos Vándorgyülése". Sopron (Hungary) 7-9 Jul 2010. Magyar Hidrológiai Társaság, Budapest, pp. 1207-1225. [in Hungarian]

Kisházi P, Ivancsics J (1985). Sopron Környéki Üledékek Összefoglaló Földtani Értékelése [Geological assessement of sediments in the neighbourhood of Sopron]. Manuscript, Sopron, Hungary, pp. 48. [in Hungarian]

Kjellström E, Nikulin G, Hansson U, Strandberg G, Ullerstig A (2011). $21^{\text {st }}$ century changes in the European climate: uncertainties derived from an ensemble of regional climate model simulations. Tellus A 63: 24-40. - doi: 10.3402/tellusa.v 63 i1.15767

Kovács A (2011). Tó- és területi párolgás becslésének pontosítása és magyarországi alkaImazásai [Specifying lake and areal evapotranspiration rates in Hungary]. PhD thesis, Vásárhelyi Doctoral School of Civil Engineering and Earth Sciences, Budapest University of Technology and Economics, Budapest, Hungary, pp. 9294. [in Hungarian]

Lutz JA, Wagtendonk JW, Franklin JF (2010). Climatic water deficit, tree species ranges, and climate change in Yosemite National Park, Journal of Biogeography 37: 936-950. - doi: 10.1111/j. 1365-2699.2009.02268.x

Maidment DR (1993). Handbook of hydrology, McGraw-Hill Education, New York, USA, pp. 563-567.

Mas-Pla J, Menció A (2019). Groundwater nitrate pollution and climate change: learnings from a water balance-based analysis of several aquifers in a western Mediterranean region (Catalonia). Environmental Science and Pollution Research 26: 2184-2202. - doi: 10.1007/s11356-0181859-8

Mingteh CS (2006). Forest hydrology: an introduction to water and forests ( $2^{\text {nd }}$ edn). Austin State University, Austin, TX, USA, , pp. 181.

Muggeo VMR (2008). Segmented: an R package to fit regression models with broken-line rela- tionships. R News, vol. 8/1, pp. 20-25. Mátyás C, Berki I, Bidló A, Csóka G, Czimber K, Führer E, Gálos B, Gribovszki Z, Illés G, Hirka A, Somogyi Z (2018). Sustainability of forest cover under climate change on the temperate-continental xeric limits. Forests 9 (8): 489. - doi: 10.3390/f9080489

Nachtnebel HP, Dokulil M, Kuhn M, Loiskandl W, Sailer R, Schöner W (2014). Influence of climate change on the hydrosphere. In: "Austrian Assessment Report Climate Change 2014 (AAR14)". Austrian Panel on Climate Change (APCC), Austrian Academy of Sciences Press, Vienna, Austria, pp. 411-466.

Nistor M, Gualtieri A, Cheval S, Dezsi S, Botan V (2016). Climate change effects on crop evapotranspiration in the Carpathian Region during 1961-2010. Meteorological Applications 23: 462469. - doi: 10.1002/met.1570

Nolz R, Cepuder P, Kammerer G (2014). Determining soil water-balance components using an irrigated grass lysimeter in NE Austria. Journal of Plant Nutrition and Soil Science 177: 237-244. - doi: 10.1002/jpln.201300335

Nolz R, Cepuder P, Eitzinger J (2016). Comparison of lysimeter based and calculated ASCE reference evapotranspiration in a subhumid climate, Theoretical and Applied Climatology 124: 315-324. - doi: 10.1007/s00704-015-1417-y

Nováky B, Bálint G (2013). Shifts and modification of the hydrological regime under climate change in Hungary. In: "Climate Change - Realities, Impacts Over Ice Cap, Sea Level and Risks" (Bharat Raj Singh ed). IntechOpen Ltd, London, UK, web site. - doi: 10.5772/54768

Pongrácz R, Bartholy J, Miklós E (2011). Analysis of projected climate change for Hungary using ENSEMBLES simulations. Applied Ecology and Environmental Research 9 (4): 387-398. - doi: 10.15666/aeer/0904 387398

R Core Team (2012). R: a language and environment for statistical computing. R Foundation for Statistical Computing, Vienna, Austria. [online] URL: http://www.r-project.org/

Rao LY, Sun G, Ford CR, Vose JM (2011). Modeling potential evapotranspiration of two forested watersheds in the southern Appalachians. Soil and Water Division of ASABE, American Society of Agricultural and Biological Engineers, vol 54 (6): 2067-2078.

Remrová M, Císlerová M (2010). Analysis of climate change effects on evapotranspiration in the watershed Uhlírská in the Jizera mountains. Soil and Water Resources 5 (1): 28-38. - doi: 10.17221/5/2009-SWR

Stagl J, Mayr E, Koch H, Hattermann FF, Huang S (2014). Effects of climate change on the hydrological cycle in Central and Eastern Europe. In: "Managing Protected Areas in Central and Eastern Europe under Climate Change" (Rannow S, Neubert $M$ eds). Springer, Dordrecht, Netherlands, pp. 31-43. - doi: 10.1007/978-94007-7960-0_3

Sun GK, Alstad J, Chen S, Chen CR, Ford G, Lin C, Liu N, Lu SG, McNulty H, Miao A, Noormets JM, Vose B, Wilske M, Zeppel Y, Zhang Z (2011). A general projective model for estimating monthly ecosystem evapotranspiration. Ecohydrology 4 (2): 245-255. - doi: 10.1002/eco.194

Szilágyi J, Józsa J (2009). Estimating spatially distributed monthly evapotranspiration rates by 
The impact of land use on future water balance

linear transformations of MODIS daytime landsurface temperature data. Hydrology and Earth System Sciences 13 (5): 629--637. - doi: 10.5194/ hess-13-629-2009

Szilágyi J, Kovacs A, Józsa J (2011). A calibrationfree evapotranspiration mapping (CREMAP) technique. In: “Evapotranspiration” (Labedzki L ed). INTECH, Rijeka, Croatia, pp. 257-274. Thornthwaite CW, Mather JR (1955). The water balance. Climatological Laboratory Publication no. 8, Drexel Institute of Technology, Philadel- phia, PA, USA, pp. 104.

Van Der Linden P, Mitchell JFB (2009). ENSEM-

BLES: climate change and its impacts: summary of research and results from the ENSEMBLES project. Met Office, Hadley Centre, Exeter, UK, pp. 160.

Var Der Linden EC, Haarsma RJ, Van Der Schrier $G$ (2019). Impact of climate model resolution on soil moisture projections in central-western Europe. Hydrology and Earth System Sciences 23: 191-206. - doi: 10.5194/hess-23-191-2019

\section{Supplementary Material}

Tab. S1 - The main properties of the applied RCMs.

Fig. S1 - The location of study areas.

Fig. S2 - Graphical representation of the model of the study areas.

Link: Herceg_3540@supplo01.pdf 